\title{
Dispersion of Mechanical Properties of Commercial Aluminum Alloys within Their Material Standards
}

Jan Serak, Dalibor Vojtech

Department of Metals and Corrosion Engineering, University of Chemistry and Technology Prague, Technicka 5, 16628 Prague 6, Czech Republic. E-mail: serakj@vscht.cz

Material standards of commercial alloys are key documents for casting producers as well as for their customers. Compliance with the prescribed chemical composition of alloys should be the basis for achieving their constant and reproducible properties. Material standards, however, in many cases tolerate contents of alloying elements within a relatively wide range, which can lead to very significant differences in mechanical properties of alloys. The differences in behavior of selected aluminum alloys with chemical composition on the lowest and highest contents of alloying elements prescribed by their material standard are documented in this paper. Significant differences in properties of alloys with chemical composition at lower and upper limits given by their material standards were found. These differences were further enhanced after heat treatment of alloys.

Keywords: Aluminum alloys, Mechanical properties, Material standards

\section{Acknowledgement}

The presented results were obtained within the frame of the research project GACR No. P108/12/G043.

\section{References}

[1] MICHNA, Š., LUKÁČ, I., OČENÁŠEK, V., KOŘENÝ, R., DRÁPALA, J., SCHNEIDER, H., MIŠKUFOVÁ, A. et. al. (2005). Encyklopedie hliniku, Adin, s. r. o., Prešov, ISBN 80-89041-88-4

[2] ČSN 42 4331. Slitina hliníku na odlitky 424331 AlSi10MgMn. 1978 (in Czech)

[3] ČSN 42 4357. Slitina hliníku na odlitky 424357 AlSi5Cu4Zn. 1978 (in Czech)

[4] ČSN 42 4315. Slitina hliníku na odlitky 424315 AlCu4Ni2Mg2. 1978 (in Czech)

[5] ČSN 42 4384. Slitina hliníku na odlitky 424384 AlSi10CuMn. 1978 (in Czech)

[6] ČSN 42 4339. Slitina hliníku na odlitky 424384 AlSi9Cu3Fe. 1978 (in Czech)

[7] ŠERÁK, J., VOJTĚCH, D., NOVÁK, P., DÁM, K. (2009). Snížení obsahu železa v hliníkových slitinách sedimentační metodou, in Proceedings of the Conference: Aluminium 2009, (ed.Technická Univerzita Košice), Staré splavy, 12.-14.10 2009, pp. 36-44

[8] ŠERÁK, J., VOJTĚCH, D., NOVÁK, P., DÁM, K., JANOUŠEK, T. (2009). The Influence of annealing conditions on microstructure of AlSiCuMgFe alloys, in Proceedings of the Conference: Metal 2009, (ed. Tanger, spol s r.o., Keltičkova 62, 71000 Ostrava), Hradec nad Moravicí, Červený zámek, 19.-21.5. 2009, pp.421-427

[9] SERAK, J., VODEROVA, M., VOJTECH, D., NOVAK, P. (2014). Microstructure and Properties of Magnesium Alloys Working at Elevated Temperatures, Manufacturing technology, Vol. 14, No. 2, 2014, pp. 238-244

[10] SERAK, J., VOJTECH, D., HYBASEK, V., SENKOVA, A., KUBASEK, J., MICHALCOVA, A., POSPISILOVA, I., FOUSOVA, M. (2016). Hydrogen Embrittlement of Biomedical Shape Memory Ni-Ti Wire, Manufacturing technology, Vol. 16, No. 5, 2016, pp. 1141-1146 